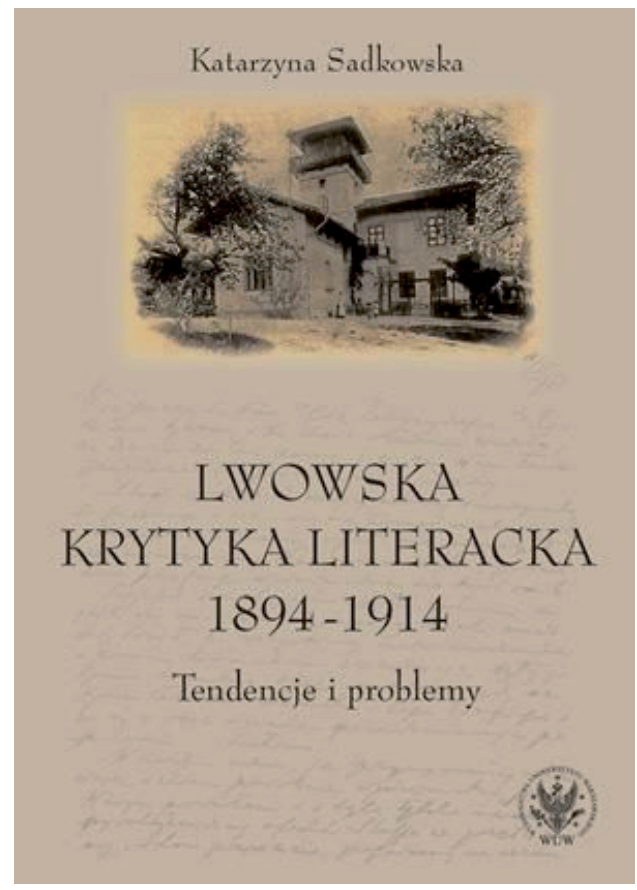

Ewa Paczoska

\section{Przywracanie głosu. Lwowska krytyka literacka}

DOI: http://dx.doi.org/10.12775/LC.2016.065

\section{B}

adania nad fenomenem kulturowym modernistycznego Lwowa, na których potrzebę tak wyraźnie wskazywał już przed laty Artur Hutnikiewicz w swojej syntezie literatury Młodej Polski, a także w monografii Stefana Grabińskiego' ${ }^{1}$, znajdują się wciąż jeszcze w fazie inicjalnej. Coraz lepiej dziś uświadamiamy sobie znaczenie tego miejsca oraz tego środowiska $\mathrm{w}$ dziejach polskiej kultury i polskiej nowoczesności. W ostatnich latach zintensyfikowały się badania nad lwowskim modernizmem, co ma też związek z odchodzeniem od stereotypu

1 Zob. A. Hutnikiewicz, Twórczość literacka Stefana Grabińskiego: 1887-1936, Toruń 1959; idem, Młoda Polska, Warszawa 1993. „krakowskiej Młodej Polski” ku pełniejszemu obrazowi epoki, o charakterze palimpsestowym. Umacnianie się tej perspektywy ma dziś również oczywiście związek z optyką badań kulturowych, przede wszystkim związanych z geografią modernizmu². Coraz ważniejsze miejsce $\mathrm{w}$ tych rozpoznaniach zajmuje pytanie o "modernizmy lokalne”, w przypadku polskim kierujące ku kontekstowi Europy Środkowo-Wschodniej ${ }^{3}$.

Tymon Terlecki przekonywał o wadze współobecności w ruchu artystycznym i kulturalnym przełomu XIX i XX w. trzech środowisk: krakowskiego, warszawskiego i lwowskiego, które dopiero widziane razem dać mogą pełny i różnorodny obraz fenomenu Młodej Polski. W młodopolskim wielogłosie każde ze wspomnianych środowisk mówiło własnym językiem, miało własne cechy szczególne i własne wersje odpowiedzi na wyzwania nowoczesności. $Z$ dużym uproszczeniem można by powiedzieć, że środowisko krakowskie używało częściej języka przeszłości, warszawskie - teraźniejszości, a lwowskie - przyszłości ${ }^{4}$. Inaczej rysowały się oczekiwania publiczności oraz dynamika życia literackiego, napędzana przez funkcjonowanie różnych jego instytucji. Środowiskowe zróżnicowanie Młodej Polski przekładało się na wybory filozoficzne, ale także genologiczne i te dotyczące środków artystycznych, oraz na stosunek do tradycji.

Widać to znakomicie na obszarze krytyki literackiej, której odrębna lwowska historia umykała dotąd często uwadze

2 Zob. E. Rybicka, Geopoetyka. Przestrzeń i miejsce we wspótczesnych teoriach i praktykach literackich, Kraków 2014 oraz Geographies of Modernism. Literatures, Cultures, Spaces, eds. P. Brooker, A. Thacker, London 2005.

3 Zob. Modernizm(y) Europy Środkowo-Wschodniej, „Przegląd Filozoficzno-Literacki” 2013, nr 1/2 (red. E. Paczoska i M. Chmurski).

4 Piszę o tym więcej w tekście Młoda Polska $i$ mapy modernizmu, w: Młoda Polska w najnowszych badaniach, red. E. Jakiel, T. Linkner (w druku).

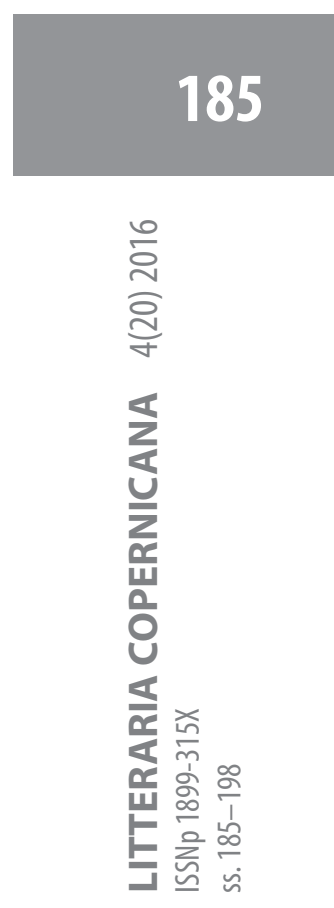


znawców przedmiotu. Krytyka literacka tej formacji, będąca awangardą intelektualną nowoczesności, nie została dotąd należycie rozpoznana, nawet specjalistom znane są głównie nazwiska Karola Irzykowskiego i Ostapa Ortwina. Jej specyfikę (i szczególność lwowskiego modernizmu) pokazują znakomicie dwie książki Katarzyny Sadkowskiej wydane w 2015 r.: Lwowska krytyka literacka 1894-1914 oraz towarzysząca jej antologia ${ }^{5}$. Wykorzystując metodologię kulturowej historii literatury, autorka rekonstruuje poszukiwania i fascynacje intelektualne krytyków działających w szczególnym środowisku. Jego wyjątkowość określały różne aspekty przywoływane i analizowane przez Sadkowską. Po pierwsze: inspiracje ze strony środowiska naukowego, bo to przecież we Lwowie można mówić o swoistym porozumieniu „mansardy” artystycznej z profesorską „katedrą”. Inspiracje te otwierały refleksję lwowskich modernistów na horyzont europejski ${ }^{6}$. Po drugie: specyficzne ulokowanie pomiędzy tym horyzontem a doświadczeniem prowincji ${ }^{7}$. Prowincji, dodajmy, wielokulturowej, kształtującej się pod wpływem bodźców rozwojowych i napięć wielokulturowości, takich jak antagonizmy pomiędzy trzema wspólnotami miasta - polską, ukraińską i żydowską. Prowincji charakteryzu-

5 K. Sadkowska, Lwowska krytyka literacka 1894 -1914. Tendencje i problemy, Wydawnictwo Uniwersytetu Warszawskiego, Warszawa 2015 oraz Programy i dyskusje lwowskiej krytyki literackiej. Antologia, wyb., wstęp i oprac. K. Sadkowska, Wydawnictwo Wydziału Polonistyki UW, Warszawa 2015 (książka wydana w serii „Doświadczenie Europy Środkowo-Wschodniej w kulturze modernizmu”; celem tej serii jest rozpoznanie szczególności owego doświadczenia i przybliżenie zjawisk marginalizowanych dotąd w badaniach m.in. wskutek stosowania kategorii „centrum” i „peryferii” wobec modernizmu europejskiego).

6 Zob. J. Woleński, Kraków, Lwów i filozofia polska na przetomie XIX i XX wieku, w: Kraków i Galicja wobec przemian cywilizacyjnych (1866-1914). Studia i szkice, red. K. Fiołek, M. Stala, Kraków 2011.

7 Zob. J. Purchla, Kraków i Lwów wobec nowoczesności, w: Kraków i Galicja wobec przemian cywilizacyjnych (1866-1914). Studia i szkice. jącej się również swoistą atmosferą patriotyczną, którą tworzyli tu m.in. uczestnicy powstania styczniowego, a także aktywiści prężnie działających instytucji ruchu stowarzyszeniowego. Po trzecie: bodźce związane $\mathrm{z}$ miejską, industrialną nowoczesnością - nie przypadkiem jako datę inicjalną interesującego ją okresu Sadkowska wybiera rok 1894, rok Powszechnej Wystawy we Lwowie $^{8}$. Po czwarte w końcu: wyzwania płynące ze strony rozwijającego się żywo w tym mieście nurtu kultury popularnej. Idąc tropem wskazanych tu aspektów, autorka świetnie pokazuje specyfikę tego środowiska, zwracając też uwagę na napięcia między odczuwaną przez lwowskich literatów zaściankowością a ich ambicjami, by włączać się w życie artystyczne europejskiej moderny (zob. rozdział Lwów nie każdemu $z$ drów?).

Bohaterami książki Sadkowskiej są przedstawiciele drugiego pokolenia Młodej Polski, którzy dokonują rozliczenia $\mathrm{z}$ doświadczeniami kryzysu lat 90. XIX w. i rewolucji 1905 r., dążąc do zbilansowania efektów przemian światopoglądowych i estetycznych. Rozliczają się także z Młodą Polską krakowską z okresu „Życia” i warszawską, tą spod znaku „Chimery” Miriama. Przedmiotem ataków krytyki bywa w związku z tym nie tylko zmora „filisterstwa”, ale także widmo... modernizmu traktowanego jako bezrefleksyjnie przyjmowana etykieta czy usprawiedliwienie intelektualnej miałkości. To właśnie perspektywa modernistycznej „autokorekty” czy poszukiwanie własnej formuły modernizmu nadaje lwowskiej krytyce początku XX w. szczególny ton.

$\mathrm{Na}$ kształt tej krytyki, jak pokazuje autorka, oddziaływały różne, często przeciw-

8 Zob. mój tekst Stolica nowoczesności?, w: Modernistyczny Lwów. Teksty życia, teksty sztuki, red. E. Paczoska, D. M. Osiński, Warszawa 2009. 
stawne tendencje światopoglądowe: projekty „filozofów życia” (z Nietzschem na czele), empiriokrytycyzm i pragmatyzm (Macha oraz Williama Jamesa), marksizm, w końcu, co może szczególnie ważne, filozofia i działalność Kazimierza Twardowskiego9. To Twardowski uczył krytyków lwowskich (takich jak Ortwin, który uczęszczał do niego na zajęcia o metodach badań naukowych i ze wstępu do psychologii eksperymentalnej) reguł wnioskowania filozoficznego. Pokazywał dwoistość słowa jako wytworu aktywności intelektualnej i psychofizycznej, a przede wszystkim - przekonywał, za Franzem Brentano, że metoda filozofii, a więc także estetyki, nie różni się od metod nauk ścisłych.

W tym pejzażu intelektualnym uwaga krytyków skupiała się oczywiście przede wszystkim na zagadnieniach sztuki i jej związków z naturą oraz życiem społecznym. Ramę dla ich poszukiwań stanowiło modernistyczne przekonanie, że, jak przypomina autorka, zadaniem sztuki jest substytucja „stworzenie zhumanizowanej syntetycznej jedności świata, nieobecnej w chaotycznej i zmiennej rzeczywistości pozaludzkiej" ${ }^{\prime 10}$. Wychodząc od tego fundamentalnego dla wspólnoty modernistycznej stwierdzenia, lwowscy krytycy wybierali jednak, jak pokazuje Sadkowska, swoistą propozycję lektury, antropologii, estetyki. Jej cechy szczególne to m.in. traktowanie krytyki jako dziedziny twórczości artystycznej (ale w innym sensie niż ten wynikający np. z wzorca „krytyki impresjonistycznej” spod znaku Ignacego Matuszewskiego) oraz łączenie krytyki z filozofią i głęboką refleksją estetyczną. Najważniejszy krąg zagadnień związanych z literaturą wyznacza w tekstach krytyków lwowskiej moderny psychologiczna

9 Zob. J. Woleński, Filozofia szkoty lwowsko-warszawskiej, Wrocław 1989.

10 K. Sadkowska, op. cit., s. 15. estetyka odbioru, z którą ściśle łączy się pojmowanie kategorii prawdy i koncepcja mimesis. Ważną cechą lwowskiej krytyki było też zaangażowanie $\mathrm{w}$ europejskie dyskusje estetyczne i w kształtowanie europejskiego horyzontu kulturowego. Także - ich zbiorowy wysiłek nakierowany na wypracowanie pewnego wspólnego sposobu analizy, interpretacji i oceny dzieł literackich oraz rozmaitych zjawisk współczesności. W tej ramie funkcjonuje swoisty „skład zasad” tej krytyki i tworzy się szczególny styl uprawiania przez nią refleksji o literaturze.

Ten bowiem zbiorowy wysiłek interesuje autorkę tak samo jak indywidualne poszukiwania największych „gwiazd” lwowskiego środowiska intelektualnego, takich jak Irzykowski i Ortwin. Ten ostatni (słusznie) jest na pewno głównym bohaterem książki Sadkowskiej, ale otaczają go tu krytycy mniej znani, tacy jak Stanisław Womela, Władysław Witwicki czy Tadeusz Sobolewski, i ci całkiem już zapoznani (Marian Olszewski, Stanisław Dąbrowski). Zyskują tu nie tylko głos, ale także - biografie. Ich pochodzenie z „prowincji”, bunt wobec polskiej tradycji rodzinnej, doświadczenie intelektualnego dojrzewania w wielokulturowym Lwowie składają się na interesujący zapis polskiej biografii modernistycznej. W biografii tej ważne miejsce zajmują też takie elementy jak walka z konsumpcjonizmem i intelektualną zaściankowością.

Głosy krytyków przypomina opracowana przez Sadkowską antologia, stanowiąca materiałową bazę jej badań nad modernistyczną krytyką lwowską. Widać tu efekty rozległych kwerend prasowych i archiwalnych prowadzonych przez autorkę w bibliotekach Lwowa i Wrocławia. W zbiorze tym pojawiają się teksty istotne dla badań nad polskim modernizmem, które nie trafily do kanonicznych Programów i dyskusji literackich okresu Młodej Polski, przygotowanych 
niegdyś przez Marię Podrazę-Kwiatkowską. Teksty znane badaczom Młodej Polski (jak np. Czym jest Horla? Irzykowskiego) zyskują tu nowe konteksty, dociekliwie zbadane i zanalizowane przez autorkę $\mathrm{w}$ książce Lwowska krytyka literacka. Sadkowska grupuje materiał antologii według najważniejszych problemów ujawniających się w dyskusjach tego środowiska. Krytyka literacka traktowana jest tu dość szeroko - podobnie jak w twórczości prezentowanych w zbiorze autorów. W antologii znalazły się zatem teksty o sztuce, rozpoznania filozoficzne, świadectwa poglądów na różne kwestie społeczne. Ten zakres dyskursów widać w układzie książki, na który składają się części: 1. Programy i forpoczty, 2. Zagadnienia psychologii odbioru, 3. O prawdę w sztuce, 4. O krytyce literackiej, 5. Literatura. Uwidaczniają się w nich indywidualne praktyki i style poszczególnych krytyków, ale uwyraźnia się także (co podkreśla autorka opracowania we wstępie) ponadindywidualny sposób uprawiania refleksji o literaturze i życiu.

Warto przyjrzeć się bliżej choćby jednej z dyskusji, wybranej przez autorkę antologii i analizowanej w książce. Dyskusja wokół tekstu Władysława Witwickiego O stosunku natury do sztuki z roku 1906, w której wzięli udział Womela, Marian Olszewski i Ortwin, pokazuje nie tylko intelektualny przebieg tej debaty, ale pozwala także wniknąć w jej ducha, zobaczyć krytyków w perspektywie dynamicznego dialogu, ocenić jego strategie (np. w momencie, gdy Ortwin zarzuca Witwickiemu „nieprzyzwoity” dla estetyka dystans wobec dzieła sztuki). Takiej temperatury i takiego poziomu intelektualnego nie miała chyba żadna inna $\mathrm{z}$ ówczesnych dyskusji o prawdzie w sztuce. Dyskusja ta potwierdza także opinię Włodzimierza Boleckiego, że, wbrew stereotypom, refleksja na temat realizmu i realności to bardzo ważny element moder- nistycznej świadomości estetycznej ${ }^{11}$. W tej debacie Witwicki wychodzi od rozpoznań Stanisława Witkiewicza, co pozwala zobaczyć miejsce tego ostatniego nie tylko w roli inspiratora tatrzańskich fascynacji artystów przełomu XIX i XX w., ale, co ważniejsze, jako prawdziwego promotora poważnej refleksji estetycznej tego czasu. Mam też poczucie, że w obszarze krytyki literackiej tamtego okresu być może nikt oprócz krytyków lwowskich nie podjął poważnego dialogu z estetyką Witkiewicza. W refleksji Witwickiego, który pisze: „natura nie jest dla sztuki pierwowzorem, tylko materiałem, jeśli przez naturę rozumiemy ogół tego wszystkiego, co tylko dany człowiek może w pewnej chwili spostrzec. Dzieło sztuki powstaje tą drogą, że artysta na naturze dokonuje abstrakcji, czyli zwraca szczególną uwagę na pewną tylko grupę elementów o jednolitym charakterze poznawczym i uczuciowym, i ta dopiero przezeń wytworzona harmonijna kombinacja jest pierwowzorem dla jego dzieła" ${ }^{12}$ - można dostrzec echa Witkiewiczowskich refleksji o realizmie i warunkach prawdy w sztuce. Ideał najwybitniejszych krytyków lwowskich, jak podkreśla autorka, to literatura autonomiczna, ale nie oderwana od rzeczywistości.

Model krytyki, który wyłania się z książki Sadkowskiej i potwierdza w przygotowanej przez nią antologii, przekracza zaproponowaną przez Michała Głowińskiego w jego książce o młodopolskiej krytyce metaforę „ekspresji i empatii”" ${ }^{3}$. Charakterystyczną cechą lwowskiej krytyki jest bowiem dążenie do obiektywizmu i naukowej rzetelności. Przypomnianych przez Sadkowską autorów

\footnotetext{
11 Zob. W. Bolecki, Wyznaczniki prozy wczesnego modernizmu, w: tenże, Modalności modernizmu. Studia, analizy, interpretacje, Warszawa 2012, s. 306.

12 Cyt. za: Programy i dyskusje lwowskiej krytyki literackiej, s. 164.

13 Zob. M. Głowiński, Ekspresja i empatia. Studia o młodopolskiej krytyce literackiej, Kraków 1997. Książka ta nie miała zresztą, jak się wydaje, ambicji syntetycznych.
} 
łączy poszukiwanie kryteriów obiektywizujących dyskurs krytyczny. Chodzi im:

o odnalezienie porządku i aktywną intelektualną rekonstrukcję duchowych procesów i stanów dzięki ich utrwaleniu. Problemem kluczowym krytyki stało się pytanie: jak treść indywidualnego przeżycia wewnętrznego, treść „ja” artysty stała się treścią „dla innych, dla nas" i jak krytyka, uspołeczniając tę treść przez wyrażenie w kategoriach mogących uchodzić za obiektywne i racjonalnie weryfikowalne, ma nie zatracić jej niepowtarzalności? Oparcie sądu na quasi-obiektywnych kryteriach miało umożliwić porównywanie i hierarchizowanie poszczególnych dzie1 ${ }^{14}$.

Te ambicje lwowskich krytyków zbliżają ich bez wątpienia do krytyki pozytywistycznej. To jej przedstawiciele, tacy jak Piotr Chmielowski, wspominany już Stanisław Witkiewicz czy Antoni Sygietyński, stworzyli podstawy polskiej krytyki literackiej traktowanej jako oddzielna gałąź refleksji estetycznej ${ }^{15}$. Wpisując się, jak pokazuje autorka, $\mathrm{w}$ przełom antypozytywistyczny, lwowscy krytycy, moim zdaniem, absorbują jednocześnie główne dokonania krytyki literackiej pozytywistów, zwłaszcza te związane $\mathrm{z}$ kształtowaniem się standardów dotyczących obowiązków krytyka i podstawy jego ocen. Szkoda, że autorka nie przyjrzała się w swojej książce możliwościom tego dialogowania - ale oczywiście wskazuje na nie jej analiza dokonań lwowskich krytyków, w których poziom estetyczny jest wciąż konfrontowany z poziomem etycznym. Nawiązując dialog

\footnotetext{
14 K. Sadkowska, op. cit., s. 17. Krytycy lwowscy nawiązując dialog z krytyką pierwszego i drugiego pokolenia pozytywistów, włączają się w wysiłek kształtowania krytyki jako dyscypliny autonomicznej, obdarzonej szczególnym językiem i formułującej szczególne cele intelektualne i społeczne.

15 Zob. moją książkę Krytyka literacka pozytywistów, Wrocław 1988.
}

z krytyką pierwszego i drugiego pokolenia pozytywistów, lwowscy moderniści kontynuują wysiłek kształtowania języka krytyki jako dyscypliny autonomicznej, obdarzonej szczególnym językiem i formułującej własne cele intelektualne i społeczne. Łącząc ze sobą różne inspiracje końca XIX w., lansują swoisty model indywidualnego opanowania rzeczywistości. Jak pisze autorka: „Krytyk miał ostatecznie zapanować nad dziełem, co wykluczało poprzestanie na rekonstrukcji przez wczucie i domagało się jasnego i uargumentowanego możliwie obiektywnie sądu. Koncepcja dzieła powstającego jako wynik świadomego i aktywnego wysiłku artysty została przyjęta także w krytyce, pełniąc poza tym funkcję aprobowanej postawy egzystencjalnej"16.

Ważną inspiracją dla lwowskiego środowiska intelektualistów był najciekawszy chyba polski krytyk i filozof przełomu XIX i XX w., czyli Stanisław Brzozowski. W książce Sadkowskiej staje się on, w pewnym sensie, krytykiem lwowskim. Nie tylko możemy tu go zobaczyć w kawiarni „Kryształowa” w słynnym pasażu Mikolascha, dokąd lubił zachodzić, ale, przede wszystkim, spojrzeć na jego dzieło z nowej perspektywy. Brzozowski, który we Lwowie wygłasza swoje słynne wykłady, testuje Legendę Młodej Polski, by w końcu, jak się mówiło w epoce, istnieć tu „zamogilnie” za sprawą swoich dzieł wydawanych przez Ostapa Ortwina, okazuje się tu ważnym ogniwem poszukiwań i fascynacji lwowskiej krytyki literackiej. To ona zresztą, jak można powiedzieć po lekturze książki Sadkowskiej, stanowiła jego „naturalne" i najbliższe otoczenie. Brzozowski dzieli z lwowskimi krytykami ambicje filozoficzne, nakierowanie na antropologiczny horyzont nowoczesności, troskę o naukowe standardy oceny. Oczywiście, oddziela

\footnotetext{
16 K. Sadkowska, op. cit., s. 311.
} 
go od nich często styl uprawiania krytyki, swoista „namiętność”, a nawet histeryczność dyskursu, która przekłada się na cechę parataktyczności ${ }^{17}$. Sadkowska dociekliwie tropi ślady obecności Brzozowskiego jako „krytyka lwowskiego” przede wszystkim $\mathrm{w}$ analizie praktyki i teorii krytycznoliterackiej Ortwina. Nie chce zresztą w Ortwinie widzieć tylko „ambasadora Brzozowskiego”. Pokazuje go jako w pełni świadomego kontynuatora myśli autora Idei, odczuwającego z nim głęboką wspólnotę - i na polu krytyki traktowanej jako sposób przezwyciężania tragizmu życia (bo krytyk uczestniczy w „tragedii poznania”), i w obszarze niepokoju metafizycznego. Ortwin spotyka się tu nie tylko z Brzozowskim, ale także z Williamem Jamesem oraz Johnem Henrym Newmanem.

Rozpoznania i refleksje związane z działalnością Ortwina jako krytyka i opiekuna spuścizny Brzozowskiego prowadzą już w stronę krytyki literackiej międzywojnia. Autorka niejednokrotnie przekracza przyjętą przez siebie datę końcową rozpoznań, by pokazać „dalsze ciągi” i kontynuacje dokonań lwowskiej krytyki. Prowokuje to czytelnika jej książki do postawienia pytania, co z nich i jak przetrwało do naszej współczesności. Na ile formuła krytyki, traktującej utwór literacki jako labirynt, w którym przed oczami odbiorcy szuka się drogi do centrum sensu, okazała się owocna i atrakcyjna dla następnych pokoleń krytyków? Arcyciekawe wydają się tu rozpoznania autorki związane z krytyką personalistyczną okresu międzywojnia. Można by do nich dorzucić jeszcze inne tropy kontynuacji - jak np. działalność Artura Sandauera. O innym z możliwych tropów mówił na niedawnej konferencji na temat Irzykowskiego Włodzimierz Bolecki, wpisując Janusza Sławińskiego jako badacza

17 Zob. M. Głowiński, Wielka parataksa, w: idem, op. cit. literatury w tradycję krytyki lwowskiej ${ }^{18}$. "Zamogilna” historia tej krytyki pozostaje ciągle do napisania.

Przybliżając „tendencje i problemy” lwowskiej krytyki literackiej, Sadkowska jest dość ostrożna w ocenie jej dokonań co może stanowić i zaletę, i wadę rozpoznań autorki. $\mathrm{Z}$ jednej strony pokazuje bowiem wyraźnie, że, jak pisze we wstępie do antologii, „z punktu widzenia stopnia intelektualizacji i unowocześnienia polskiej refleksji estetycznej, jej »europeizacji«, Lwów wysuwa się na plan pierwszy $\mathrm{w}$ porównaniu z ówczesnym Krakowem i Warszawą"19. $\mathrm{Z}$ drugiej - próbuje uzgodnić swoje opinie $\mathrm{z}$ ustaleniami Głowińskiego na temat młodopolskiej krytyki literackiej, z którymi tak naprawdę nie zawsze dają się uzgodnić. Ostrożnie też ocenia samodzielność lwowskiego środowiska, podkreślając, że mimo sporych ambicji przede wszystkim podejmowało ono twórczy dialog z ideami przychodzącymi z Zachodu, że mało było tu w pełni własnych rozpoznań i diagnoz związanych z sytuacją kultury. A przecież analizy autorki przynoszą obraz niezwykłej samodzielności i autonomiczności oferty intelektualnej krytyków lwowskich. Uprawiana przez nich filozofia kultury daje się bez kompleksów porównywać z takimi autorami z kręgu modernistycznej rewolty intelektualnej, jak Simmel, Croce, Lucacs czy Benjamin. Pytania pozostają tu i tam wspólne - i wspólne są ambicje związane $\mathrm{z}$ rozpoznawaniem procesów rozwojowych kultury.

Obie książki Katarzyny Sadkowskiej udowadniają, że ciągle jeszcze mało wiemy o polskim modernizmie przełomu XIX i XX w., którego awangardą była właśnie lwowska krytyka literacka. Autorka wska-

\footnotetext{
18 Zob. Karol Irzykowski - cztowiek sporu, postać sporna, red. M. Chmurski, K. Sadkowska (w druku).

19 Programy i dyskusje lwowskiej krytyki literackiej, s. 17.
} 
zuje bowiem i w głównym, i w pobocznym nurcie swojej refleksji zapomnianych autorów i niewydane ciągle teksty, które domagają się włączenia do głównego nurtu badań nad historią polskiej kultury. Ich przywrócone przez Sadkowską głosy kierują w stronę postulowanego przez badaczy polskiego modernizmu „powrotu do Lwowa” - nie w sensie podróży sentymentalnej, lecz w znaczeniu intelektualnej wyprawy ku źródłom naszej nowoczesności.

Prof. dr hab. Ewa Paczoska - dyrektor Instytutu Literatury Polskiej na Uniwersytecie Warszawskim, kierownik Pracowni Literatury Modernizmu w Europie Środkowowschodniej. E-mail: ewapaczoska@interia.pl. 